\title{
Influence of the capillary pipe geometry on the energy efficiency of household refrigerator
}

\author{
Hristo Hristov ${ }^{1}$, Apostol Simitchiev $^{1 *}$, and Donka Stoeva ${ }^{1}$ \\ ${ }^{1}$ University of Food Technologies, Plovdiv, Bulgaria, Department of MAFFI, Maritza 26, blvd.
}

\begin{abstract}
The energy efficiency of household refrigerating appliances was measured according to EN ISO15502. A Liebherr IKP 1650 built-in Domestic refrigerator is used to determine the influence of the capillary pipe geometry. The temperatures at the injection site of the refrigerant, the inlet and outlet of the evaporator receiver were measured. The obtained results show that there is no universal optimal geometry of the capillary pipe. There is no element of the refrigeration cycle whose change has no effect on the refrigerant flow rate passing through the capillary pipe. A change in the geometry of capillary pipe affects all other components of the refrigeration cycle and can greatly improve or impair the efficiency of the refrigerator. The potential for switching from one to two different geometries of the capillary pipe is approximately $8 \%$ improvement in energy consumption. Possible implementation should take into account the potential savings $\sim 8 \%$ and the life cycle of the particular appliance $(\sim 15$ years). For the particular measured device, the consumption per year is about $75 \mathrm{kWh}$, which should take into account that the device itself has a low volume and low energy consumption.
\end{abstract}

\section{Introduction}

Anyone who nowadays would like to be engaged in scientific research on throttling capillary pipes in refrigeration technique should ask themselves if there is anything new to be discovered in this field. Capillary pipes have been used as an expansion body in refrigeration since the 1920 s to the present day $[1,2]$. The first scientific publications were published in 1946 and the first practical optimizations were made in 1957 [3]. Studies in this area are of great interest to many scientists involved in refrigeration. The reason for this is the huge use of the capillary pipe - till 1953 only 300,000 refrigerators per year were produced. Today only in Plovdiv, Bulgaria the factories produce 3,000 daily or 1 million per year. Each household has at least one refrigerator or air conditioner in which the refrigerant is throttled by a capillary pipe.

Capillary pipes are currently the cheapest mass-produced expansion part in refrigeration [4]. This is mainly due to the simple construction - usually 2 to 6 meters long copper pipes with an inside diameter of 0.5 to $2 \mathrm{~mm}$. They have no moving parts or are sensitive to external influences and, unlike conventional expansion valves (thermostatic or electric)

*Corresponding author: asimitchiev@gmail.com 
have much higher reliability [5]. However, despite its simple design, as a result of the regenerative heat exchange with suction pipe used in domestic refrigerators, the capillary pipe is one of the most complex elements $[6,7]$. The complexity stems from the ever changing ambient temperature and heat load of the system. This leads to a number of problems in their design, which in many cases prove ineffective.

\subsection{Thermodynamic processes during throttling in a capillary pipe}

The thermodynamic processes in a capillary pipe are most clearly illustrated by a diagram of temperature and pressure Fig. $1[8,9]$. The depiction assumes that the refrigerant leaves the condenser in a state of cooled liquid and that there is no heat exchange in the regenerative heat exchanger.

The capillary pipe connects the condenser to the evaporator. The refrigerant enters it with condensation pressure and at the outlet it exits with approximate evaporation pressure. At the inlet, it may be a cooled liquid, a saturated liquid or a vapor mixture. Due to the sharp shrinkage of the cross section at the inlet of the capillary pipe, the refrigerant undergoes pressure loss. In the diagram shown in Fig.1, this phenomenon is highly overexposed and practically the losses are within a few millibars, which is difficult to prove with measurements.

However, with the slight cooling in the domestic refrigerators, it plays a significant role as steam bubbles can form, which can lead to noise and flow instability. Therefore, refraction of the capillary pipe should be avoided. The picture presented at Fig. 2 shows a refraction of a capillary pipe.

By using coils around the filter dehydrator, heat exchange is obtained between the refrigerant in the filter dehydrator and the capillary pipe. This leads to the presence of steam bubbles and thus loss of refrigeration capacity. The coils around the filter dehydrator are classified as an energy-innefficient design solution.

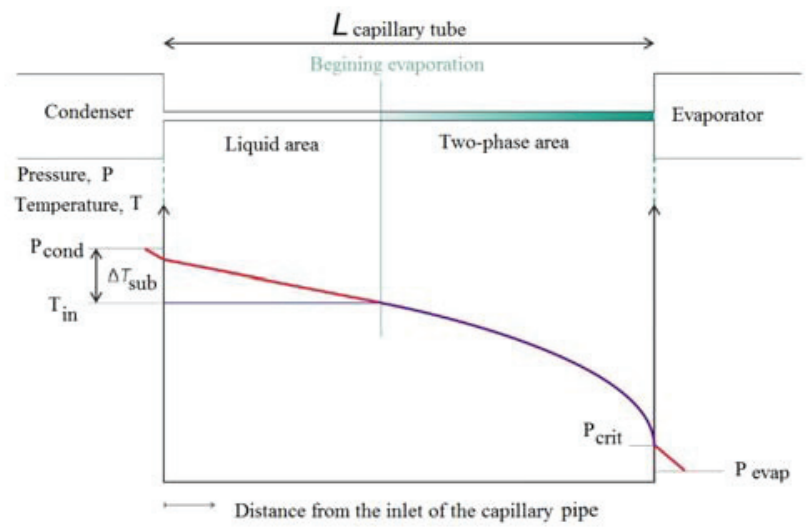

Fig. 1. Diagram of temperature and pressure in a capillary pipe in the absence of regenerative heat exchange.

After entering the capillary pipe, the refrigerant in the liquid condition is throttled approximately isothermic Fig.1. The pressure decrease in proportion to the length. Fluid heating around $0.6 \mathrm{~K} / \mathrm{m}$ due to dissipation could be expected here. In real conditions, the pressure at which evaporation begins is reached well below the saturation pressure. An overheated liquid is formed, as shown in Fig.1 with the intersection of pressure and temperature lines. The moment the evaporation begins leads to a sharp decrease of the overheating. In the next two-phase flow, steam and liquid are in thermos-dynamic 
equilibrium due to the intense mixing. Lowering the pressure causes the liquid to evaporate, which is why the average density decreases and the speed of the two phases increases (Table 1). This leads to two mutually reinforcing effects: due to the acceleration, the pressure decreases and the flow at a higher speed has greater pressure losses (friction). These two effects lead to an increasingly upward pressure line. The mass flow rate and density of the refrigerant reaches critical value Pcrit, which depends only on the input parameters. Subsequent lowering of the pressure after the capillary pipe cannot lead to an increase of the mass flow rate. Therefore, when considering the processes in the capillary pipe, the evaporation pressure does not play a role.

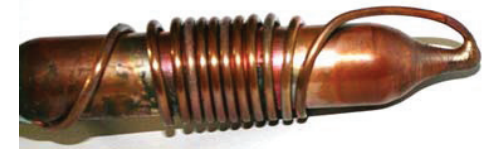

Fig. 2. Refraction and winding of the capillary pipe on the filter dehydrator.

When cooled liquid enters the capillary pipe, the fluid area increases. Unlike the twophase region, the relative pressure losses in the liquid region per unit length of the capillary pipe are much smaller. In other words: there is an inverse correlation between the mass flow rate in the capillary pipe and the relative fraction of the two-phase region.

The heat exchange between the suction and capillary pipes in the regenerative heat exchanger leads to an increase in the specific cooling capacity, but also to an increase in the energy consumption of the compressor. In the case of domestic refrigerators, the specific operation of the compressor at R600a is little less dependent on the suction temperature, and the suction gases from the compressor are warmed almost to ambient temperature due to the lack of insulation on the suction pipe. This is to avoid hydraulic shock. Refrigeration capacity that cannot be supplied to the capillary pipe by the suction pipe is lost in the area after the heat exchanger and the compressor inlet into the environment.

Table 1. Refrigerant parameters at inlet and outlet of adiabatic capillary pipe (homogeneous flow).

\begin{tabular}{|c|c|c|c|}
\hline Parameter & $\begin{array}{c}\text { Inlet ofcapillary } \\
\text { pipe }\end{array}$ & $\begin{array}{c}\text { At the beginning of } \\
\text { two-phase region }\end{array}$ & $\begin{array}{c}\text { Outlet of } \\
\text { capillary } \\
\text { pipe }\end{array}$ \\
\hline Vapor content\%, & 0 & 5 & 23 \\
\hline Density, $\mathrm{kg} / \mathrm{m}^{3}$ & 551 & 119 & 12 \\
\hline Speed, $\mathrm{m} / \mathrm{s}$ & 2 & 8 & 80 \\
\hline
\end{tabular}

\section{Materials and methods}

\subsection{Energy efficiency and standards}

The European certificate for energy efficiency of large domestic appliances was introduced in 1996. This resulted to an increase in production of highly efficient refrigerators.

Domestic refrigerators intended for the European market were measured in accordance with EN62552; EN153; EN ISO15502. After 2020 to assess energy efficiency and better compare different products worldwide (incl. Australia, China, Europe) we have moved towards a unified so-called Global standard IEC 62552 (Global Standard). For ISO 15502:2005 measurements, only one ambient temperature $\left(25^{\circ} \mathrm{C}\right)$ is required to determine energy consumption. Systems marketed in Europe are now optimized for these conditions only. The main feature that matters in the choice of the geometry of the capillary tube is the 
fact that in the new standard, energy efficiency will be measure at 2 ambient temperatures $\left(16^{\circ} \mathrm{C}\right.$ and $\left.32{ }^{\circ} \mathrm{C}\right)$ as a opposed to the current $25^{\circ} \mathrm{C}$. Summary of the difference between the two standards is shown on Table. 2.

Table 2. Standards.

\begin{tabular}{|c|c|c|}
\hline Standard & $\begin{array}{l}\text { EN62552; } \\
\text { EN153; EN } \\
\text { ISO15502 } \\
\end{array}$ & $\begin{array}{l}\text { IEC } 62552 \\
\text { (Global } \\
\text { Standard) } \\
\end{array}$ \\
\hline \multirow{4}{*}{ 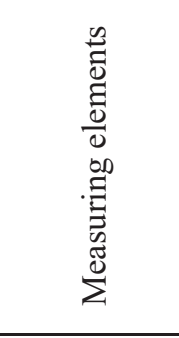 } & $\begin{array}{l}\text { Refrigerating part: } \\
\text { PT100 }\end{array}$ & $\begin{array}{l}\text { Refrigerating part: } \\
\text { PT100 }\end{array}$ \\
\hline & $\begin{array}{l}\text { Chiller part: } \\
\text { packages }\end{array}$ & $\begin{array}{l}\text { Chiller part: } \\
\text { PT100 }\end{array}$ \\
\hline & $\begin{array}{l}\text { Freezer part: } \\
\text { packages }\end{array}$ & $\begin{array}{l}\text { Freezer part: } \\
\text { PT100 }\end{array}$ \\
\hline & $\begin{array}{l}\text { Wineries: } \\
\text { packages }\end{array}$ & Wineries: PT100 \\
\hline $\begin{array}{l}\text { Ambient } \\
\text { temperature }\end{array}$ & $25^{\circ} \mathrm{C}$ & $16^{\circ} \mathrm{C}$ and $32^{\circ} \mathrm{C}$ \\
\hline \multirow{4}{*}{ 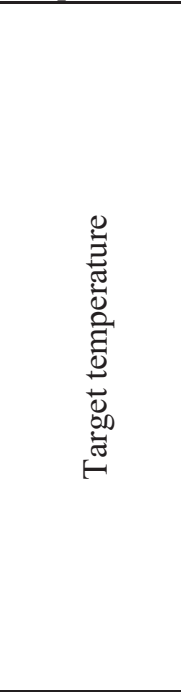 } & $\begin{array}{l}\text { Refrigerating part: } \\
\mathrm{T}_{\mathrm{M}}=5,0^{\circ} \mathrm{C} \\
\text { (Average of three } \\
\text { PT100) }\end{array}$ & $\begin{array}{l}\text { Refrigerating part: } \\
\mathrm{T}_{\mathrm{M}}=4,0^{\circ} \mathrm{C} \\
\text { (Average of three } \\
\text { PT100) }\end{array}$ \\
\hline & $\begin{array}{l}\text { Chiller part: } \\
\mathrm{T}_{\mathrm{MAX}}=3,0^{\circ} \mathrm{C} \\
\text { (maximum for all } \\
\text { packages) }\end{array}$ & $\begin{array}{l}\text { Chiller part: } \\
\mathrm{T}_{\mathrm{M}}=2,0^{\circ} \mathrm{C} \\
\text { (maximum of } \\
\text { three PT100) }\end{array}$ \\
\hline & $\begin{array}{l}\text { Freezer part: } \\
\mathrm{T}_{\mathrm{MAX}}=-18^{\circ} \mathrm{C} \\
(\text { maximum } \\
\text { temperature of all } \\
\text { packages) }\end{array}$ & $\begin{array}{l}\text { Freezer part: } \\
\mathrm{T}_{\mathrm{M}}=-18^{\circ} \mathrm{C} \\
\text { (Mean average of } \\
\text { all PT100) }\end{array}$ \\
\hline & $\begin{array}{l}\text { Winery: } \mathrm{T}_{\mathrm{M}}= \\
12^{\circ} \mathrm{C} \\
\text { (Average of all } \\
\text { packages) }\end{array}$ & $\begin{array}{l}\mathrm{WT}: \mathrm{T}_{\mathrm{M}}=12^{\circ} \mathrm{C} \\
\text { (Average of three } \\
\text { PT100) }\end{array}$ \\
\hline
\end{tabular}

\subsection{Measuring energy efficiency}

The energy efficiency class shows the energy consumption of the refrigeration unit when compared to another with the same volume and purpose. It is determined in accordance with Regulation (EC) № 643/2009 of the European Parliament. The so-called energy efficiency index is used to determine the energy efficiency class. It represents the ratio of actual consumed electricity per year to standard consumption per year $[10,11]$

$$
E E I=\frac{A E}{S A E} \cdot 100=\frac{E_{24 h} \cdot 365}{V_{e q}+M+N+C H} \cdot 100 \quad, \%
$$

Where AE - actual consumed electricity per year, kWh; SAE - standard consumption per year, kWh; Veq - equivalent volume of domestic refrigerating appliance; $\mathrm{M}, \mathrm{N}$ - values 
selected from tables, depending on the category; $\mathrm{CH}-50 \mathrm{kWh} /$ per year in the compartment for perishable products with a volume of at least 15 liters.

\subsection{Nitrogen flow rate}

Determining the inside diameter of a capillary pipe at a given pressure drop is a difficult task. Even the slightest deviation of the inner diameter of the tolerances has a noticeable effect. For this reason, in practice, instead of the inside diameter, the most commonly used is the nitrogen $\left(\mathrm{N}_{2}\right)$ flow rate, under certain initial conditions [12]. The methodology for measuring $\left(\mathrm{N}_{2}\right)$ flow rate is defined in DIN8905 Part 3. In the measurements, despite the different physical processes of refrigerant throttling and a practically ideal gas (such as $\mathrm{N}_{2}$ ), conclusions can be drawn regarding the linear relationship between the flow rates of $\mathrm{N}_{2}$ and the actual flow rate of the refrigerant in the system, subject to the initial conditions:

1. Increasing the $\mathrm{N}_{2}$ flow rate of a capillary pipe by about $10 \%$, by reducing the length or choosing a larger internal diameter, results in an increase in the refrigerant flow rate by about $10 \%$. Unless the length of the regenerative heat exchanger changes.

2. If the capillary pipe is replaced by a shorter one, which, however has the same nitrogen flow rate, it can be expected that if the operating parameters are maintained the refrigerant flow rate remains unchanged. Unless the regenerative heat exchanger changes (especially the length) in all other cases the flow rates must be calculated on a case by case basis. Different flow rates will also lead to a different optimal refrigerant volumes.

\subsection{Determining the optimum amount of refrigerant}

Determining the optimum amount of refrigerant per refrigerator for the time being is an empirical process on the principle of sample error. Refrigerant is added until overheating of the evaporator outlet is within the desired range, and the suction pipe temperature must be monitored [13]. When the compressor is not running, the refrigerant is collected in the evaporator. After the start of the compressor there is a lack of refrigerant in the condenser. The refrigerant must first be moved to the condenser.

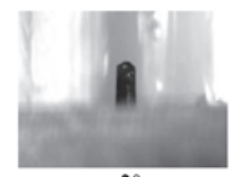

$t=20 \mathrm{~s}$

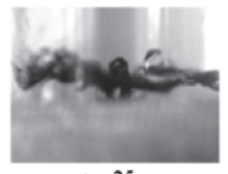

$t=25 \mathrm{~s}$

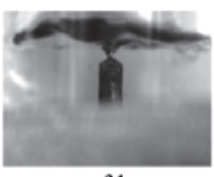

$t=31 \mathrm{~s}$

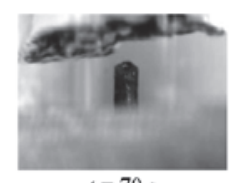

$t=70 \mathrm{~s}$

Fig. 3. Increasing the liquid piller after starting the compressor. Influence of gas amount on liquid level at condenser outlet/ capillary inlet.

\subsection{Experiment planning}

The measurements were performed using ANOVA of the type $3^{2}$ with two independent variables (nitrogen flow rate and amount of refrigerant R600a) and one response surface (energy consumption). For convenience and easier reproduction of the results, the nitrogen flow rate was presented instead of the capillary pipe's length. The measuring range was selected on the basis of the serial characteristics of the refrigerator and the practical limitations. All experiments were performed in triplets.

Multi Channel Process System (MCPS) software product was used for measurements and registration. The temperature reading is accurate to $\pm 0.15{ }^{\circ} \mathrm{C}$, and the energy consumption is $\pm 0.01 \%$. Energy efficiency research was conducted in Liebherr's laboratory. A Standard IKP 1650 refrigerator was used. It was optimized for operation at 
$25^{\circ} \mathrm{C}$. The capillary pipe is 1 to $4 \mathrm{~m}$ long and $0,6 \pm 0,025 \mathrm{~mm}$ in diameter. Length of $2,52 \mathrm{~m}$ corresponds to $4,5 \mathrm{l} / \mathrm{min}$ nitrogen flow rate according to the method shown in DIN8905 part 3 .

\subsection{Experimental installation}

A Liebherr IKP 1650 built-in domestic refrigerator is used to determine the influence of the geometry of the capillary pipe.

The temperatures at the injection site of the refrigerant, the inlet and outlet of the evaporator receiver were measured.

Table 3. Liebherr IKP 1650 built-in domestic refrigerator specification.

\begin{tabular}{|l|l|l|}
\hline Appliance & \multicolumn{1}{|l|}{ IKP1650 } \\
\hline Serial number & 31.485 .678 .2 \\
\hline Measurement number & LHG150138 \\
\hline Evaporator & roll bond & $\begin{array}{l}\text { Nitrogen flow } \\
\text { rate 4,5 1/min }\end{array}$ \\
\hline Condenser & Wire & \\
\hline $\begin{array}{l}\text { Vaccum panel in the } \\
\text { door }\end{array}$ & $7429116-00$ & $\begin{array}{l}640 \times 395 \times 11 \\
\mathrm{~mm}\end{array}$ \\
\hline $\begin{array}{l}\text { Vaccum panels in the } \\
\text { housing }\end{array}$ & $7429116-00$ & $\begin{array}{l}640 \times 395 \times 11 \\
\mathrm{~mm}\end{array}$ \\
\hline $\begin{array}{l}\text { Compressor } \\
\text { Amount of refrigerant }\end{array}$ & Inverter control \\
\hline D5bracoVES & $32 \mathrm{~g}[\mathrm{R} 600 \mathrm{a}]$ \\
\hline Volume of the refrigerant part [1] & 151 \\
\hline Climatic class & $\mathrm{SN}-\mathrm{T}$ \\
\hline Energy index & $21,9 \%$ \\
\hline Energy efficiency class & $\mathrm{A}+++$ \\
\hline $\begin{array}{l}\text { Energy consumption according to } \\
\text { ISO15502 }\end{array}$ & $0,178 \mathrm{Wh} / 24 \mathrm{~h}$ \\
\hline
\end{tabular}

\subsection{Temperature measurements}

Cold storage temperature $t_{m}$ represents the mean of the three PT100 elements during the tests $-\mathrm{t}_{1 \mathrm{~m}}, \mathrm{t}_{2 \mathrm{~m}}, \mathrm{t}_{3 \mathrm{~m}}$. 


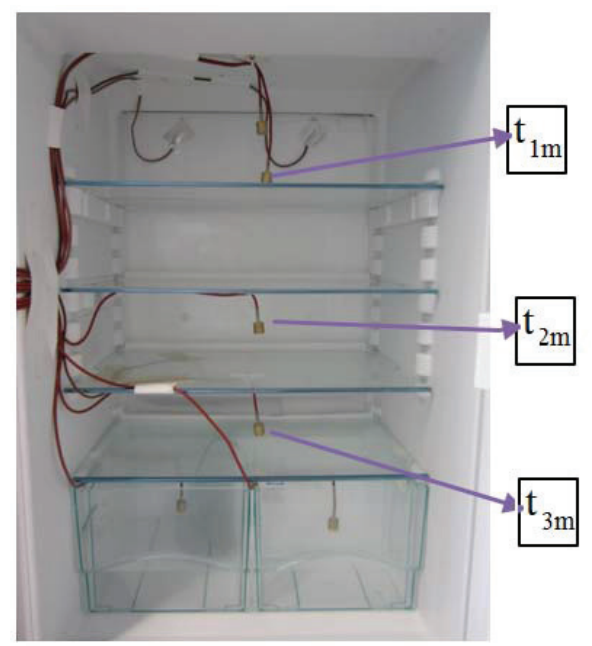

Fig.4. Refrigeration compartment.

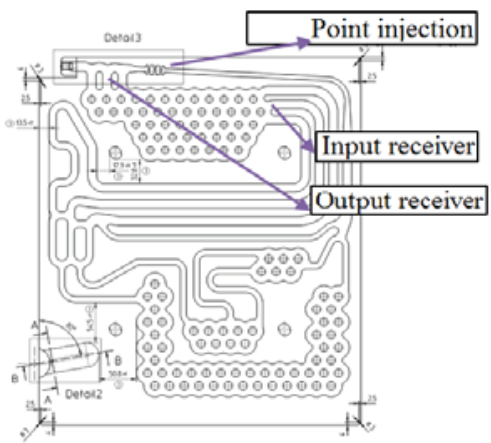

Fig.5. Evaporator.

The temperatures of the inlet, outlet and the midpoint of the condenser were measured.

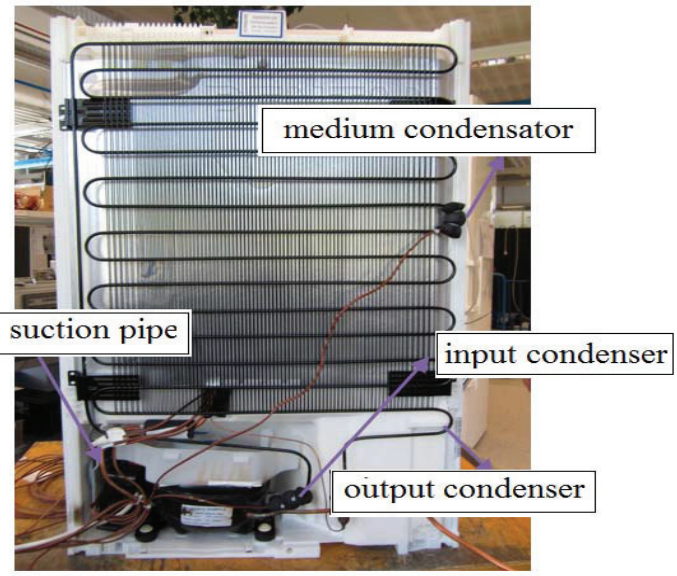

Fig. 6. Condenser. 


\section{Results and discussion}

Table 4 presents two optimal variants (LM21 and LM32) of the measurements and table 5 summarizes the results. The first measurement is on the serial device. The measurements were made by changing the geometry of the capillary pipe and the amount of refrigerant without changing the length of the regenerative heat exchanger.

Table 4. Optimal variants of the measurements.

\begin{tabular}{|l|c|c|c|c|c|c|c|}
\hline & & \multicolumn{2}{|c|}{ LM01* } & \multicolumn{2}{l|}{ LM21 } & \multicolumn{2}{l|}{ LM32 } \\
\hline Ambient temperature & & $16^{\circ} \mathrm{C}$ & $32^{\circ} \mathrm{C}$ & $16^{\circ} \mathrm{C}$ & $32^{\circ} \mathrm{C}$ & $16^{\circ} \mathrm{C}$ & $32^{\circ} \mathrm{C}$ \\
\hline Nitrogen flow rate & $1 / \mathrm{min}$ & 4,5 & 4,5 & 6,0 & 6,0 & 3,0 & 3,0 \\
\hline Refrigerant R600a & $\mathrm{g}$ & 32,0 & 32,0 & 38,0 & 38,0 & 38,0 & 38,0 \\
\hline Setting & ${ }^{\circ} \mathrm{C}$ & 4,5 & 4,5 & 4,5 & 4,5 & 5,0 & 5,5 \\
\hline Working time & $\min$ & 12,3 & 22,0 & 9,1 & 25,8 & 15,9 & 17,3 \\
\hline Rest time & $\min$ & 51,5 & 22,8 & 49,8 & 24,3 & 55,8 & 20,6 \\
\hline Working time & ${ }^{\circ}$ & 19,3 & 48,9 & 15,4 & 51,2 & 22,3 & 45,5 \\
\hline T $m$ & ${ }^{\circ} \mathrm{C}$ & 4,8 & 5,1 & 4,8 & 4,9 & 5,1 & 5,2 \\
\hline & $\mathrm{kWh} /$ & & & & & & \\
\hline Energy consumption & 24 & 0,107 & 0,314 & 0,92 & 0,328 & 0,121 & 0,295 \\
\hline PT100 (T1) & ${ }^{\circ} \mathrm{C}$ & 4,6 & 4,5 & 4,6 & 4,5 & 5,0 & 6,2 \\
\hline PT100 (T2) & ${ }^{\circ} \mathrm{C}$ & 3,9 & 3,3 & 3,8 & 3,2 & 4,4 & 5,3 \\
\hline PT100 (T3) & ${ }^{\circ} \mathrm{C}$ & 6,0 & 7,5 & 6,1 & 7,2 & 6,0 & 4,1 \\
\hline TKE01 & $\mathrm{min}$ & $-17,6$ & $-13,2$ & $-13,8$ & $-12,2$ & $-19,9$ & $-10,5$ \\
\hline Injection & ${ }^{\circ} \mathrm{C}$ & $-15,6$ & $-12,8$ & $-13,2$ & $-11,9$ & $-18,1$ & $-10,1$ \\
\hline Inlet in the receiver & ${ }^{\circ} \mathrm{C}$ & $-14,7$ & $-12,0$ & $-10,5$ & $-10,5$ & $-16,5$ & $-10,9$ \\
\hline Outlet in the reciver & ${ }^{\circ} \mathrm{C}$ & $-6,4$ & $-4,8$ & $-6,0$ & $-6,8$ & $-7,4$ & $-5,8$ \\
\hline Inlet in the condenser & ${ }^{\circ} \mathrm{C}$ & 29,3 & 48,9 & 28,7 & 50,1 & 29,0 & 47,4 \\
\hline Midpoint condenser & ${ }^{\circ} \mathrm{C}$ & 24,0 & 44,7 & 26,4 & 45,6 & 28,2 & 46,3 \\
\hline $\begin{array}{l}\text { Outlet in the } \\
\text { condenser }\end{array}$ & ${ }^{\circ} \mathrm{C}$ & 16,1 & 31,8 & 16,1 & 45,8 & 20,5 & 44,5 \\
\hline Suction pipe & ${ }^{\circ} \mathrm{C}$ & 12,5 & 27,0 & 15,3 & 29,9 & 16,2 & 24,9 \\
\hline
\end{tabular}

*Serial refrigerator data

Table 5. Summary of measurement results.

\begin{tabular}{|c|c|c|c|c|}
\hline \multirow{2}{*}{$\begin{array}{c}\text { Measurement } \\
\text { № }\end{array}$} & \multirow{2}{*}{ 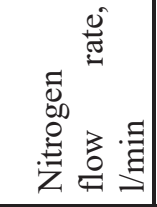 } & \multirow{2}{*}{ 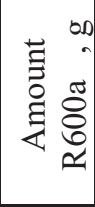 } & \multicolumn{2}{|c|}{$\begin{array}{c}\text { Energy } \\
\text { consumption } \\
\mathrm{Wh} / 24 \mathrm{~h}\end{array}$} \\
\hline & & & $16^{\circ} \mathrm{C}$ & $32^{\circ} \mathrm{C}$ \\
\hline LHG150138_M01 & 4,5 & 32 & 107 & 314 \\
\hline LHG150138-M38 & 4,5 & 33 & 103 & 322 \\
\hline LHG150138_M21 & 6 & 38 & 92 & 328 \\
\hline LHG150138_M25 & 3 & 33 & 130 & 310 \\
\hline LHG150138-M32 & 3 & 38 & 121 & 295 \\
\hline LHG150138 M30 & 4,5 & 33 & 101 & 322 \\
\hline
\end{tabular}




\begin{tabular}{|l|l|l|l|l|}
\hline LHG150138-M34 & 6 & 33 & 101 & 330 \\
\hline LHG150138_M24 & 3 & 38 & 110 & 301 \\
\hline LHG150138 M29 & 4,5 & 28 & 122 & 326 \\
\hline LHG150138 M12 & 3 & 28 & 122 & 307 \\
\hline LHG150138-M37 & 6 & 28 & 107 & 340 \\
\hline
\end{tabular}

The ANOVA table (Table 6) partitions the variability in EC 16 into separate pieces for each of the effects. It then tests the statistical significance of each effect by comparing the mean square against an estimate of the experimental error. In this case, 2 effects have Pvalues less than 0.05 , indicating that they are significantly different from zero at the $95.0 \%$ confidence level.

Table 6. Anova for EC16 and EC 32

\begin{tabular}{|l|l|l|l|l|}
\hline \multicolumn{5}{|c|}{ EC 16 } \\
\hline Source & Sum of squares & Mean square & F-ratio & P-value \\
\hline A:Flow & 534,998 & 534,998 & 22,55 & 0,0177 \\
\hline B:Charge & 240,349 & 240,349 & 10,13 & 0,0500 \\
\hline AA & 101,038 & 101,038 & 4,26 & 0,1310 \\
\hline AB & 16,8348 & 16,8348 & 0,71 & 0,4614 \\
\hline BB & 20,9426 & 20,9426 & 0,88 & 0,4167 \\
\hline Lack-of-fit & 199,97 & 39,9941 & 1,69 & 0,3540 \\
\hline \multicolumn{5}{|l|}{ EC 32 } \\
\hline A:Flow & 1086,79 & 1086,79 & 113,73 & 0,0018 \\
\hline B:Charge & 165,686 & 165,686 & 17,34 & 0,0252 \\
\hline AA & 3,25952 & 3,25952 & 0,34 & 0,6002 \\
\hline AB & 1,15 & 1,15 & 0,12 & 0,7516 \\
\hline BB & 4,17811 & 4,17811 & 0,44 & 0,5557 \\
\hline Lack-of-fit & 61,6704 & 12,3341 & 1,29 & 0,4439 \\
\hline
\end{tabular}

The lack of fit test is designed to determine whether the selected model is adequate to describe the observed data, or whether a more complicated model should be used. The test is performed by comparing the variability of the current model residuals to the variability between observations at replicate settings of the factors. Since the P-value for lack-of-fit in the ANOVA table is greater or equal to 0,05 , the model appears to be adequate for the observed data at the $95,0 \%$ confidence level.

The obtained regression equations which has been fitted to the data are:

EC $16=177,39-7,55 *$ Nitrogen flow rate $-1,04 *$ Amount R600a

EC $32=315,55+9,39 *$ Nitrogen flow rate $-1,16^{*}$ Amount R600a

Judging from the presented results and the literature analysis, it is clear that there is no universal optimal geometry of the capillary pipe. There is no element of the refrigeration cycle, whose change has no effect on the refrigerant flow rate passing through the capillary pipe. A change in the geometry of the capillary pipe affects all other components of the refrigeration cycle and can greatly improve or impair the efficiency of the refrigerator.

The potential for optimizing a single device when switching from EN ISO15502 to IEC 62552 (Global Standard) is presented in Table 7. 


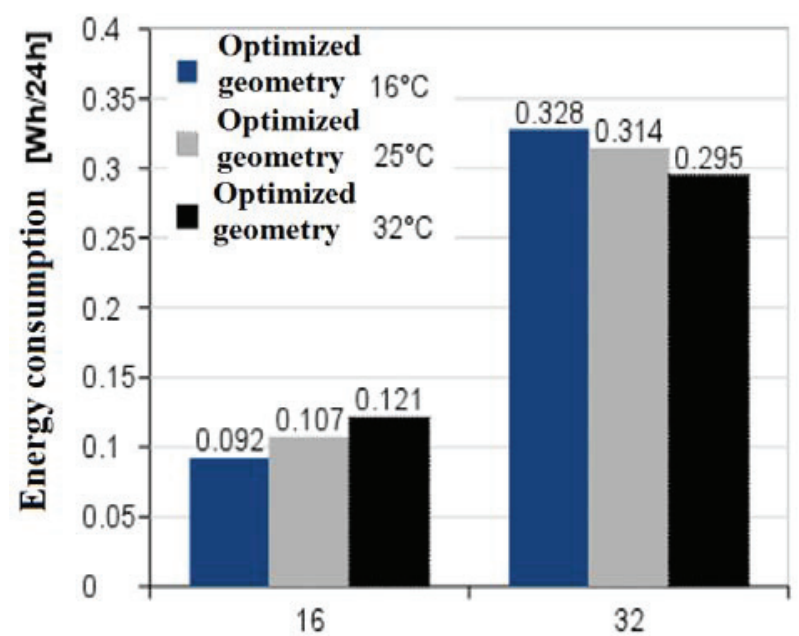

Ambient temperature $\left[{ }^{\circ} \mathrm{C}\right]$

Fig. 7. Energy consumption at different geometries of the capillary pipe.

Table 7. Potential for optimizing a single device when switching from EN ISO15502 to IEC 62552 (Global Standard).

\begin{tabular}{|c|c|c|c|c|c|c|}
\hline Measurement & 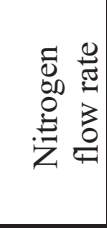 & $\begin{array}{c}\text { Amount } \\
\text { R600a }\end{array}$ & \multicolumn{2}{|c|}{ 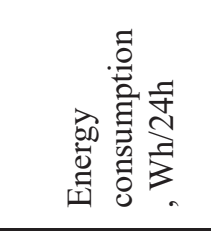 } & 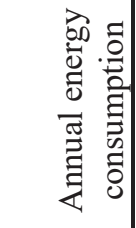 & 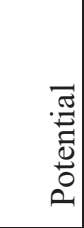 \\
\hline № & $1 / \mathrm{min}$ & $\mathrm{g}$ & $16^{\circ} \mathrm{C}$ & $32^{\circ} \mathrm{C}$ & $\mathrm{kWh}$ & $\%$ \\
\hline LM01 & 4,5 & 32 & 107 & 314 & 76,8 & - \\
\hline LM21 & 6 & 38 & 92 & & & \\
\hline LM32 & 3 & 38 & & 295 & 70,6 & 8,1 \\
\hline
\end{tabular}

\section{Conclusion}

The potential for switching from one to two different geometries of the capillary pipe is approximately $8 \%$ improvement in energy consumption. Possible implementation should take into account the potential savings $\sim 8 \%$ and the life cycle of the particular appliance $(\sim$ 15 years). For the particular measured device, the consumption per year is about $75 \mathrm{kWh}$, which should take into account that the device itself has a low volume and low energy consumption. In the specific case, after the measured improvements, it could save over 6,2 $\mathrm{kWh}$ annualy, or about $93 \mathrm{kWh}$ annualy for entire life cycle of the appliance. At an average price of $0,16 \mathrm{BGN}(0,08$ Euros) (which is likely to increase each year, taking into account the trend in recent years), such optimization would be cost-effective at a cost less than 14,9 BGN (7,62 Euros). If we consider the initial investment, in the variant with $16{ }^{\circ} \mathrm{C}$ ambient temperature, the length of the capillary pipe decreases (nitrogen flow rate $\mathrm{N}_{2}=6 \mathrm{H} / \mathrm{min}$; $\mathrm{R} 600 \mathrm{a}=38 \mathrm{~g}$ ), respectively the prime cost of the refrigerator decreases. At a high ambient temperature of $32^{\circ} \mathrm{C}$, the length of the capillary pipe increases twice (nitrogen flow rate $\mathrm{N}_{2}$ $=3 \mathrm{l} / \mathrm{min}$; R600a $=38 \mathrm{~g}$ ), which increases the cost of the refrigerator. 
The authors would like to thank Liebherr Hausgerate Maritsa for the assistant provided.

\section{References}

1. R. H. Swart, Capillary Tube Heat Exchangers, Refrigerating Engineering, Nr. 9, S. 221-224, 248-249 (1946)

2. L. Cooper, C.K. Chu, W.R. Brisken, Simple selection method for capillaries derived from physical flow conditions, Refrigerating Engineering 65, Nr. 7. p.88 (1957)

3. R. Plank, Kapitel Entwicklung/Wirtschaftliche Bedeutung, Werkstoffe (Band I), Handbuch der Kältetechnik. Springer Verlag (1954)

4. N. Ludwig, Füllen von Kälteanlagen mit Kapillareinspritzung, Die Kälte+ Klimatechnik, Nr. 2, S. 28-34 (2009)

5. L. A. Staebler, Theory and Use of a Capillary Tube for Liquid Refrigerant Control, Refrigerant Engineering 55, Nr. 1, S. 55-59, 102-105 (1948)

6. L.E. Dietsch, Das Kapillarrohr und seine Anwendung an kleinen Kältesystemen, Nr. 10 / Teil 4.1, S. 19-22 (1974)

7. H. Hristov, K. Angelov, Improving the energy efficiency of a household refrigerator I, Scientific works of the union of scientists in Plovdiv, Series B, Engineering and Technology, ISNN 1311-9419, Volume XIII, p.187-90 (2016)

8. H. Hristov, K. Angelov, Improving the energy efficiency of a household refrigerator II, Scientific works of the union of scientists in Plovdiv, Series B, Engineering and Technology, ISNN 1311-9419, Volume XIII, p.191-194 (2016)

9. C. Melo, C.B. Neto, R.T.S. Ferreira, R.H. Pereira, Constitutive Equations for Capillary Tube Modeling, Proceedings of the International Refrigeration Conference in Purdue. Paper 449, 1998, S. 431-436 (1999)

10. C. Melo, C.B. Neto, R.T.S. Ferreira, Empirical Correlations for the Modeling of R134a Flow Through Adiabatic Capillary Tubes, ASHRAE Transactions 105 (1999), Nr. 2, S. 51-59 (1999)

11. W. Bohl, W. Elmendorf, Technische Strömungslehre, 15. Auflage. Vogel Buchverlag, 2014 (Kamprath-Reihe) (2014)

12. M. Schenk, L. R. Oellrich, Experimentelle Untersuchung des Kältemitteldurchflusses von Isobutan (R600a) durch adiabate Kapillaren, Tagungsband zur DKV-Tagung 2012, Würzburg DKV, Deutscher Kältetechnischer Verein, AA II.2, S. 1-11 (2012)

13. D. Hartmann, C. Melo, Popping Noise in Household Refrigerators: Fundamentals and Practical Solution, Applied Thermal Engineering 51 (s 1-2);40-47 (2013) 